\title{
Entering the genetic arena
}

William J. Schull

Who Do You Think You Are? Man or Superman: The Genetic Controversy. By Oliver Gillie. Pp. 255. (Hart-David, MacGibbon: London, 1976.) £4.95.

OF LATE, genetics, and particularly human genetics, has found itself increasingly involved in controversial social issues; these include the roles of heredity and environment in the origin of the apparent differences in performance on intelligence tests, and the relationship, if any, of an extra $Y$ chromosome to criminality. The scientific discussion of these issues has been characterised by more intellectual arrogance and humbug than seems generally to prevail. I had hoped that this little volume might redress these excesses in a trenchant way. It does not. Who do you think you are? has a catchy title, a few provocative thoughts, but is generally disappointing. We are confronted with clichés, and an overly pejorative division of the world into hereditarians and environmentalists. The attributes imputed to these groups would be worthy of a medieval scholastic obliged to account for the presence of evil in a world produced by a deity intrinsically good. What of value can possibly come from further polarisation of the attitudes toward these problems? These are strong, possibly intemperate remarks to some. Let me document them.

We find on p14 such simple clichés about political beliefs as, "'Liberal' or 'radical' scientists tend to be 'environmentalists' and 'conservative' scientists tend to be 'hereditarians' who believe that heredity is of preeminent importance in deciding character. This is exactly what we might expect when we reflect that it is conservatives who always have the greatest interest in property and titles-that is, the greatest vested interest in non-biological inheritance." Or on pp109-110 we are treated to an analysis of Johannes Lange's personal prejudices and how the latter coloured not only the data on criminality he collected but his interpretations of these data as well. These accusations may indeed be true, but the cast of the argument seems to indict all "hereditarians" but exonerate "environmentalists" of this not so admirable human failing. One wonders whose prejudices are showing here. The larger issue, or so it seems to me, is not whether Lange or others exhibit prejudices but what is the sequence of events or experiences, cultural or biological, which gives rise to them. Selfserving irrelevancies are everywhere. The late Trofim Lysenko is described as being "from a simple peasant background" (p24); arguments which the author favours are prefaced with remarks such as "few serious scientists now dispute' (p128)--the implication is clear. Darlington's Genetics and Man doubtlessly deserves the criticisms which Gillie levels, but who other than he has ever characterised Genetics and Man as a "major work on the biology of man" (p95)?

There are, moreover, simple mistakes. DNA is said to have been discovered in 1953 (p20); this is the year in which its structural form was first identified but its chemical composition had been known for almost a century at that time. The inheritance of aryl hydrocarbon hydroxylase as here described (p129), has not been confirmed although the relationship of the inducibility of this enzyme to lung cancer seems still to hold. Although the book is generally well produced from the printer's vantage point, there are a

few ludicrous misprints. I'll cite one. The dust jacket identifies William Shockley as Schockley, which in view of the racism of which he is charged, or at best the naive succour of racists ascribed to him, borders on shtick.

I cannot urge the reader of this review to dash out and purchase Who Do You Think You Are? for unless he or she belongs to the uncertain audience to which it is addressed he (or she) will be disappointed. As I attempted to imply at the outset, the book could have been more, and Oliver Gillie could have written one which would serve our time importantly. I fear, however, he has pandered where he should have been principled; has been simplistic where he should have been simple; has polarised where he should have been understanding; and has generally failed to appreciate the power of satire, if his intent is to serve a particular cause or point of view. I would urge, as a model, he read (or reread) Haldane's Politics and Heredity, an opus of the $30 \mathrm{~s}$, before he ventures into this arena again.

William J. Schull is Director of the Center for Demographic and Population Genetics at the University of Texas Health Science Center, Houston, Texas.

\section{Nucleic acid treatise}

Photochemistry and Photobiology of Nucleic Acids. Edited by Shih Yi Wang. Vol. 1: Chemistry. Pp. xv+576. (Academic: New York and London, 1976.) $\$ 54$; 229.50 .

THIS is the first of a two-volume treatise the purpose of which is to summarise our present knowledge of the photochemistry and photobiology of nucleic acids. The present first volume deals with the physical and chemical processes induced by absorption of a photon in nucleic bases-including rare and synthetic ones-as well as their monomeric and polymeric derivatives. The second volume is devoted to the DNA photochemistry and the photobiological aspects.

Each chapter is written by a group of workers, who are specialists in their respective fields. The basic concepts in the domain of photochemistry are first outlined, followed by a complete and up-to-date review on the excited states of nucleic acids. Emphasis is, of course, placed on the new and exciting developments concerning room temperature emission.

The main core of the volume is the description of those photoproducts known so far. Particularly pertinent is the analysis of the photohydrates and of the cyclobutane-type photodimers. The volume succeeds in presenting a balanced point of view on conflicting datas or interpretations coming from different groups, and discloses to the reader the problems that remain to be resolved.

Interesting chapters are devoted to the other pyrimidine adducts, the list of which is rapidly expanding, and to the purine photochemistry. In particu- 